\section{Elinvar Hairsprings in Watches}

R. E. GouLd hảs recently published a paper on the comparative performance of watches with the usual eut bimetallic balance wheels and steel hairsprings, and those of the new form having uncut monometallic balance wheels and elinvar hairsprings (Bureau of Standards J. Res., 12, April 1934). Elinvar is a nickel-steel alloy having a temperature coefficient of elasticity which is practically zero from $5^{\circ}$ to $35^{\circ} \mathrm{C}$. $\left(41^{\circ}\right.$ to $95^{\circ} \mathrm{F}$.). In the new watches the balance wheel is non-magnetic. The experiments show that the temperature-rate errors of the watches having the new vibrating assembly were smaller than the errors with ordinary watches. Instead of the usual parabolic curve of errors a curve approaching a straight line was obtained. The use of the new assembly ensures a very marked improvement in the performance of the watches. The new arrangement almost entirely overcomes the effects of magnetism, so that after a watch has been subjected to a strong magnetic field the rate is not affected. Very few watches maintain an absolutely uniform rate as the mainspring unwinds. If the number of seconds lost or gained since winding be plotted against time after winding, true 'isochronism' is represented by a straight line. So far as 'isochronism' goes, the new assembly does not give any material advantage over the old. Also various small changes, caused by altering the positions of the watches, are practically the same in both types.

\section{Thames Estuary Fisheries}

Mr. LaURence Wells, who has from time to time contributed articles to the Southend newspapers based on the notes of the late Mr. James Murie, has recently published two more, the "Whitebait Industry" and the "Spratting Industry" (Southend Pictorial Tele. graph, April 14 and May 24, 1934). Nearly two hundred years have passed since whitebait was first fished for, and the industry was much more important a hundred years ago than it is to-day. There are, however, signs of revival in the trade, and now there are more whitebait in the river than the merchants can dispose of, although one hundred and fifty years ago it was prophesied that within ten years the river would be denuded of fry. Sprat-fishing is apparently on the decline, and the only salvation for the Thames spratters is the canning industry which is here described. Mr. Wells goes into the history of both fisheries and the methods of capture, giving details of the eatches of whitebait, which mainly consists of the fry of herrings and sprats but may contain also about twenty other species of young fishes. He also describes the proper way to cook it, and how to distinguish the herring of whitebait size from that of the sprat.

\section{Rabbits and Traps}

THE next Parliamentary session will see a bill introduced in the House of Lords by Lord Tredegar to prohibit the use of the steel trap. This bill is now in the final stages of drafting by the University of London Animal Welfare Society, which, as the result of a recent questionnaire, claims to be in possession of overwhelming evidence in favour of the abolition of the trap, both on humanitarian grounds andstrange to relate-because it is claimed that trapping results in a continuance of the rabbit pest. This claim is founded on the experience of certain landowners, who have abandoned trapping for other methods of extermination simply because they have found that extermination was not to be achieved by means of the trap. Landowners may be deemed to be impartial in a matter of this kind ; for, naturally, they desire to keep rabbits down. They are also keenly alive to the dangers of the steel trap to fox-hounds, domestic animals, partridges and other game. Another of their objections to the steel trap is that it kills stoats, ferrets and other natural enemies of the rabbit pest.

\section{Speed of Snakes}

THE general notion that snakes attain great speed of movement is not supported by timed observations made in the United States, and described in a paper read by Dr. Walter Mosaner before the American Association for the Advancement of Science at Berkeley, California (Science Service, Washington, D.C.). Of seven typical North American snakes tested, the red racer was the speediest with a record of three and a third miles an hour, while the Californian boa, moving at a rate of only a quarter of a mile an hour, was the slowest. The author considers that the mistaken idea about the speed of snakes arose from the deceptiveness of the smooth, fluent, undulatory movement, but he admitted that his records might possibly be broken by snakes doing sudden bursts under stress of excitement, and by some tropical snakes which may double or treble the American records.

\section{Mosasaurian Skeletons from Manitoba}

According to the Times, the National Museum at Ottawa, Canada, has lately received two nearly complete Mosasaurian skeletons from an Upper Creta. ceous clay in southern Manitoba. They measure respectively $33 \mathrm{ft}$. and $15 \mathrm{ft}$. in length, but both lack the end of the tail. Only fragments of these fossil marine reptiles have hitherto been found in Canada, and our knowledge of the group depends chiefly on well-preserved skeletons from the yellow chall of Kansas, U.S.A. The new specimens were collected, and are now being prepared for study, by $\mathrm{Mr}$. Charles M. Sternberg, son of Mr. Charles H. Sternberg, who collected most of the specimens from Kansas.

\section{A New Platinum Mineral}

Prof. O. Zvjaginstsev, of the Russian Platinum Institute, Moscow, has reported, according to the Prager Presse of August 18, that a new mineral has been found associated with platinum ores. It contains iridium, osmium, gold and ruthenium as well as platinum. The mineral has a silver-white appear. ance, is very hard but brittle and has a high specific gravity. Considerable development has recently taken place in the mining of precious metals in Russia. 
Last year, for example, as much as $87,000 \mathrm{kgm}$. of pure gold was extracted, and this exceeded the Canadian production. It also represented an increase of forty per cent over the amount obtained in 1932. More still is expected to be obtained in the present year.

\section{Grassland Research in Australia}

$I_{T}$ is not often that research workers are able to review the whole field of their particular investigation in their own country, but grassland agronomists in Australia are placed in this fortunate position by the appearance of Bulletin No. 14 of the Herbage Publication Series of the Institute of Agricultural Botany ("Grassland Research in Australia", Imperial Bureau of Plant Genetics, Aberystwyth, Great Britain, 3s., February 1934). The bulletin contains a comprehensive survey of Australian research work on pasture management and improvement, the genetics, pests and diseases of grass crops, poisonous plants, the introduction of new species and plant physiology as it relates to grasses. For each research centre, the names of the investigators, the scope of the work, experimental procedure and references to published results are given. Two original papers on "The Technique of Pasture Investigations" by J. Griffiths Davies and H. C. Trumble, and "Botanical Analysis of Irrigated Pasture" by E. S. Beruldsen and $\mathbf{A}$. Morgan are also included in the bulletin.

\section{Physics in National Planning}

IN an article on this subject which Prof. Karl T. Compton, of the Massachusetts Institute of Technology, contributes to the July issue of the Review of Scientific Instruments, he points out that physics has given birth to nearly all those ideas which have led to the understanding and use of the forces of Nature ; that almost every branch of industry has benefited from it, and that the pace at which it is developing at the present time assures us of its increasing power to help in the future. A nation which, by anti-educational policy or by inadequate provision for research, puts itself industrially at the mercy of more progressive nations, is courting economic distress and unemployment for the next generation. He considers that the United States Government, in spending only one half of one per cent of its annual budget on its scientific bureaux, is showing a lamentable lack of vision. He urges re-consideration of the place of science in national planning and policy, and better provision for it in the future.

\section{The U.S. National Research Council}

IN several issues of Science during 1933, articles by various authors have appeared surveying the organisation of, and suggestions for needed changes in, the United States National Research Council. These articles have now been issued in pamphlet form as a partial record of the accomplishments of the National Research Council ("A History of the National Research Council, 1919-1933". Washington, D.C. 1933. 50 cents). A survey of the organisation and activities of the Council is contributed by Dr.
Albert L. Barrows, its assistant secretary. The Council originated in an offer made by the National Academy of Sciences of its services to President Wilson in 1916, when it was seen that the United States would become involved in the War. The Council was finally established as a perpetual body on May 18, 1918. The organisation and activities of the following divisions are described by their respective chairmen: Physical Sciences, Prof. F. K. Richtmeyer; Engineering and Industrial Research, Prof. Dugald C. Jackson, Chemistry and Chemical Technology, Prof. Charles A. Kraus; Geology and Geography, Prof. W. H. Twenhofel ; Medical Sciences, Prof. Stanhope Bayne-Jones; Biology and Agriculture, Prof. Fernandus Payne; Anthropology and Psychology, Prof. A. T. Poffenberger. An account of the Research Information Service is contributed by its director, Dr. Clarence J. West, and the assistant secretary of the Council describes the various divisions of general relations (federal, foreign, States and educational). A list of publications is appended.

\section{History of Medicine Congress}

THIS year's Congress of the German Society of the History of Medicine will form part of the ninety-third Congress of the Society of German Men of Science and Physicians, which will be held at Hanover on September 18-19. The following subjects, among others, will be considered: bone finds in the Alamannic graves, by Prof. Georg Sticker ; racial ideas in India, by R. F. G. Moller; Velasquez and the doctrine of heredity by Prof. Haberling; a contribution to the study of medicinal plants, by Edith Heischkel; Cæsarean section by midwives, by Elsaluise Haberling; Novalis and Romanticism, by Prof. Paul Diepgen; Urso, the last doctor, philosopher and theologian at Salerno, by Dr. Rudolf Creotz; the medical faculty at the University of Tyrnau, by Prof. T. von Gyorgi; the correspondence of Drs. Zimmermann and Espenburg with Kotzebue, by Dr. W. Leibbrand; Kestren, the Frankfort municipal doctor, by Dr. Kallmorgen; national and politica1 tendencies in the congresses for natural science 1822-48, by Dr. Ludwig Englert, and Caspar Friedrich Wolff, by Dr. Julius Schuster. Further information can be obtained from Dr. W. Artelt, Universitatsstrasse $3 \mathrm{~b}$, Berlin, N.W.7.

\section{Sixth International Congress for Scientific Management}

Ax the Sixth International Congress for Scientific Management to be held in July of next year, arrangements have been made for the discussion of many papers giving accounts of management in relation to a variety of problems. These include business forecasting, budgetary control, the inculcation of best methods of management, production control and technique, standardisation, the distribution problems of manufacturers, wholesalers and retailers, selective education and training for high administrative positions. Many international and national problems would be affected by the greater use of scientific method. The management of 